\title{
Validated Stability-Indicating Derivative Spectrophotometry and Synchronous Fluorescence Spectroscopy Methods for the Determination of Dapoxetine Hydrochloride in the Presence of its Degradation Product and Co-Formulated Drugs
}

\author{
Suzan Mahmoud Soliman ${ }^{1^{*}}$, Heba MY El-Agizy ${ }^{1}$ and Abd El Aziz El Bayoumi ${ }^{2}$ \\ ${ }^{1}$ National Organization for Drug Control and Research (NODCAR), Giza, Egypt \\ ${ }^{2}$ Analytical Chemistry Departments, Faculty of Pharmacy, Cairo University, Cairo, Egypt
}

*Corresponding author: Suzan Mahmoud Soliman, Suzan Mahmoud Soliman, National Organization for Drug Control and Research (NODCAR) El Agoza, Giza, 12311, Egypt, Fax: +2-02-23379445; Tel: +2-02-26496077; E-mail: suzansoliman1961@hotmail.com

Received date: Aug 08, 2017; Accepted date: Oct 05, 2017; Published date: Oct 10, 2017

Copyright: (c) 2017 Soliman SM, et al. This is an open-access article distributed under the terms of the Creative Commons Attribution License, which permits unrestricted use, distribution, and reproduction in any medium, provided the original author and source are credited.

\begin{abstract}
The stability of dapoxetine hydrochloride (DP) was studied in the presence of its acidic degradation product namely, (+)-N, N-dimethyl-1-phenyl-3-propanolamine (Deg 1) and the co-formulated drugs Vardenafil (VR) and Tadalafil (TD) using derivative spectrophotometry and synchronous fluorescence spectroscopy methods.

Method I, stability indicating derivative spectrophotometry 1D was developed for the determination of DP in the presence of its hydrolytic degradation product and the co-formulated drug VR. The amplitude of the first derivative spectra $1 \mathrm{D}$ at $\lambda \max$ of $240 \mathrm{~nm}$ and $227 \mathrm{~nm}$ was measured for DP and VR, respectively.

Method IIA, stability indicating synchronous fluorescence spectroscopy (SFS) was described for the determination of DP in the presence of its hydrolytic degradation product and the co-formulated drug TD. In this method (SFS) was performed at $\Delta \lambda$ of $70 \mathrm{~nm}$ in acetonitrile medium and the synchronous fluorescence intensities of TD were measured at $212 \mathrm{~nm}$.

Method IIB, The first derivative synchronous fluorescence spectra FDSFS were applied for measuring the amplitudes of FDSFS at $295 \mathrm{~nm}$ and $242 \mathrm{~nm}$ for analysis of DP and TD, respectively.

The degradation products was obtained in acidic stress condition of $5 \mathrm{M}$ hydrochloric acid, separated, and identified by IR and mass spectrometry to confirm its structure, and elucidate degradation pathway. The methods were applied for stability-indicating assay of DP (method I and II), VR (method I) and TD (method II) in bulk powders, laboratory prepared mixtures and co-formulated pharmaceutical preparations containing degradation product of DP. The results obtained were satisfactory compared with those obtained from the comparison methods and no significant differences were found. The two stability indicating methods were validated as per ICH guidelines.
\end{abstract}

Keywords: Stability-indicating spectroscopy methods; Degradation pathway; Dapoxetine; Vardenafil; Tadalafil

\section{Introduction}

Dapoxetine hydrochloride

(DP); (S)-N,

N-dimethyl-3(naphthalen-1-yloxy)-1-phenyl propan-1-amine hydrochloride, (Figure 1); is a short-acting selective serotonin reuptake inhibitor that is rapidly absorbed and eliminated in the body. It is one of the most potent drugs that are recently used for the treatment of premature ejaculation (PE) in men. It can be taken in combination with other PDE-5 inhibitors, since it doesn't show any pharmacokinetic interactions $[1,2]$.

Vardenafil (VR); 4-[2-Ethoxy-5-(4-ethylpiperazin-1-yl) sulfonylphenyl]-9-methyl-7-propyl-3, 5, 6, 8-tetrazabicyclo[4.3.0]nona-3,7,9trien-2-one, (Figure 1), and Tadalafil (TD); (6R-trans)-6-(1,3benzodioxol-5-yl)-2, 3, 6, 7, 12, 12a-hexahydro-2-methyl-pyrazino [1', $\left.2^{\prime}: 1,6\right]$ pyrido[3,4-b]indole-1,4-dione, (Figure 1), are selective long- acting phosphodiesterase- 5 inhibitors that are as well very effective in the treatment of erectile dysfunction. The maximum recommended dose is $20 \mathrm{mg}$ per day for VR and TD [3-5].

Snovitra Super Power tablets and T-ject $^{\bullet}$ tablets are novel prescription drugs that combine Dapoxetine hydrochloride DP with Vardenafil VRand DP with Tadalafil TD, respectively, to improve male sexual health. These combinations were introduced recently into the market as novel co-formulated drugs due to the synergistic effect of these drugs in the treatment of PE and ED [6,7]. The assay of the proposed drugs in their drug substances and co-formulated preparations are not officially recorded in any pharmacopoeia; therefore much more investigations are required for their analysis.

A literature survey revealed that the simultaneous determination of DP and VR (method I) was addressed in few methods. These involve the use of spectrophotometry, derivative synchronous fluorescence spectroscopy; thin layer chromatography and high performance liquid chromatography for analysis of the selected drugs in combined dosage form [8-13]. 
Citation: Soliman SM, El-Azizy HMY, EI Bayomi AEA (2017) Validated Stability-Indicating Derivative Spectrophotometry and Synchronous Fluorescence Spectroscopy Methods for the Determination of Dapoxetine Hydrochloride in the Presence of its Degradation Product and Co-Formulated Drugs. Pharm Anal Acta 8: 564. doi:10.4172/2153-2435.1000564

Page 2 of 11

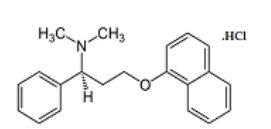

DP
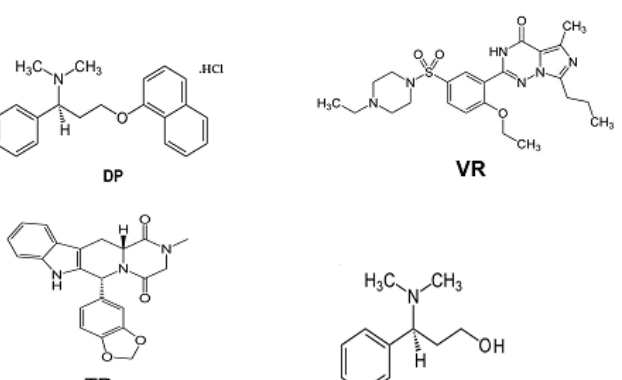

TD

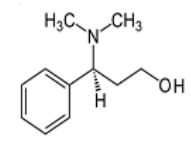

Deg 1

Figure 1: Chemical structure of Dapoxetine hydrochloride (DP), Vardinafil (VR), Tadalafil (TD) and degradation product of DP (Deg 1).

Few analytical procedures have been reported for the simultaneous determination of DP and TD (method II) in bulk powder and coformulation. These procedures include spectrophotometry, synchronous fluorescence spectroscopy and high performance liquid chromatography [14-17].

For commercial samples containing DP alone, spectrophotometric methods are reported in the recent literature [18-20]. HPLC methods have also been reported for determination of DP enantiomer, process related impurities and metabolites in pharmaceutical preparations and/or biological samples [21-23].

Although there are reported stability-indicating HPLC methods for analysis of DP in bulk drug and formulation to the best of our knowledge, the two stability indicating 1D spectrophotometry and first derivative synchronous fluorescence spectroscopy methods FDSFS for determination of DP in the presence of its hydrolytic degradation product and its co-formulated drugs VR and TD have yet been developed before [24,25].

Up till now neither stability-indicating 1D and FDSF methods nor possible degradation mechanism has been reported for determination of DP in the presence of its hydrolytic degradation product and its coformulated drugs VR and TD. The proposed methods able to prevent cross-interferences arising from absorption and/or emission by DP hydrolytic degradate and its co-formulated drugs VR and TD. Therefore; the aim of the present study is to develop simple, inexpensive and selective two stability-indicating 1D and FDSFs methods for analysis of the cited drugs in drug substances, laboratory prepared mixtures and co-formulated pharmaceutical preparations containing acidic degradation product of DP namely, (+)-N, Ndimethyl-1-phenyl-3-propanolamine (Deg 1) (Figure 1).

\section{Experimental}

\section{Instrumentation}

Spectrophotometer: A double beam PerkinElmer UV-visible spectrophotometer connected to a Perkin Elmer UV Win lab Explorer software. The spectral slit width was $2 \mathrm{~nm}, \Delta \lambda$ was $4 \mathrm{~nm}$, scaling factor (CF) was 10 and scanning speed was $480 \mathrm{~nm} / \mathrm{min}$.

Spectrofluorometer: The fluorescence spectra and measurements were recorded using Hitachi F 7000 fluorescent; model 5J1-0004 connected with FL Solutions 2.1 Software program. It is equipped with a 150 watt Xenon arc lamp. Ex and Em slit was $10 \mathrm{~nm}$. Scan speed was $12000 \mathrm{~nm} / \mathrm{min}, \Delta \lambda$ was $70 \mathrm{~nm}$ and PMT Voltage was $400 \mathrm{~V}$.

Additional instruments were used including: A thermostatic water bath (Memmert, Germany), a Rotavapor (Buchi, Switzerland), a sonicator (crest, New York), a digital pH meter (Hanna pH211, Romania), TLC aluminum sheets $(20 \mathrm{~cm} \times 20 \mathrm{~cm}, 0.2 \mathrm{~mm})$, Silica gel F254 (Merck KGaA Darmstadt, Germany) and a UV lamp with a short wavelength of $254 \mathrm{~nm}$ (Desaga Germany).

\section{Materials and methods}

\section{Authentic samples}

Dapoxetine and Vardenafil standard materials were kindly supplied by Inspire Pharma, Lilly-Egypt. Their purity was found to be $99.31 \% \pm$ $0.61 \%$ and $99.38 \% \pm 1.54 \%$ for DP and VR, respectively, according to the reference HPLC method. The quantification of the two drugs was carried out on C18 column and a mobile phase consisting of buffer $\left(\mathrm{KH}_{2} \mathrm{PO}_{4}\right)$ : acetonitrile: triethylamine $(55: 45: 0.1 \mathrm{v} / \mathrm{v} / \mathrm{v})$ at $266 \mathrm{~nm}$ [13].

Dapoxetine and Tadalafil standard materials were kindly supplied by Bayer medical companies-Egypt; the purity was found to be $99.22 \%$ \pm 1.35 and $99.02 \pm 1.02 \%$ for $\mathrm{DP}$ and TD, respectively, according to the reference HPLC methods. Determination of the two drugs was achieved on C18 column using a mobile phase consisting of acetonitrile: $0.1 \%$ triethyl amine in water $\mathrm{pH} 4.0(80: 20)$ at $229 \mathrm{~nm}$ [16].

\section{Market samples}

Snovitra Super Power ${ }^{\oplus}$ tablets (batch No. 108002) labeled to contain $60 \mathrm{mg}$ of DP base equivalent to $67.162 \mathrm{mg}$ of Dapoxetine $\mathrm{HCl}$ and 20 $\mathrm{mg}$ of VR per tablet in a ratio of 3:1 was purchased from online pharmacy.

T-ject ${ }^{\circ}$ tablets (batch No. 176030) labeled to contain $60 \mathrm{mg}$ of DP and $20 \mathrm{mg}$ of TD per tablet in a ratio of 3:1 was manufactured by Spier and purchased from online pharmacy.

\section{Chemicals and solvents}

HPLC grade acetonitrile was Lab-Scan (Poland), while methanol and ethanol were Fischer Chemical (UK).

\section{Degradation of the sample}

$100 \mathrm{mg}$ of DP refluxed with $100 \mathrm{ml}$ of $5 \mathrm{M} \mathrm{HCL}$ solution in a $250 \mathrm{ml}$ round bottom flask for $30 \mathrm{~h}$ at $90^{\circ} \mathrm{C}$. The sample tested for complete degradation by TLC using toluene-methanol $(8.5: 1.5 \mathrm{v} / \mathrm{v})$ as a mobile phase and the developed plates were visualized at $254 \mathrm{~nm}$ under a UV lamp. Only one spot was observed not corresponding to DP. The degraded solution was then cooled and neutralized with $5 \mathrm{M} \mathrm{NaOH}$ until $\mathrm{pH}$ 7. The solution was evaporated on a water bath nearly to dryness, cooled and transferred into a $100 \mathrm{ml}$ volumetric flask with methanol. The volume was completed to the mark with methanol and filtered. The degraded solution was used for the IR and mass spectral scan and for testing the two stability-indicating methods. 


\section{Standard and degradation product solutions}

Stock standard solutions of DP and VR (Method I): Stock standard solutions of $1 \mathrm{mg} / \mathrm{mL}$ of each of DP and VR were prepared in methanol. Further dilution was prepared in methanol to obtain working standard solutions of $(0.1 \mathrm{mg} / \mathrm{mL})$ of each drug.

Stock standard solutions of DP and TD (Method IIA and IIB): Stock standard solutions of $0.1 \mathrm{mg} / \mathrm{mL}$ of each of DP and TD were prepared in acetonitrile. Further dilution was prepared in acetonitrile to obtain working standard solutions of $(0.01 \mathrm{mg} / \mathrm{mL})$ of each drug.

Stock degradation product solution $(1 \mathrm{mg} / \mathrm{ml})$ in methanol: The solution was prepared by refluxing $100 \mathrm{mg}$ of DP with $100 \mathrm{ml}$ of $5 \mathrm{M}$ $\mathrm{HCl}$ solution in $250 \mathrm{ml}$ round bottom flask for $30 \mathrm{~h}$ at $90^{\circ} \mathrm{C}$. The degraded solution was then cooled and neutralized with $5 \mathrm{M} \mathrm{Na} \mathrm{OH}$ until $\mathrm{pH}$ 7. The solution was evaporated on a water bath nearly to dryness, cooled and transferred into a $100 \mathrm{ml}$ volumetric flask with methanol. The volume was completed to the mark with methanol and filtered.

Working degradation product solution (DP Deg I) $0.1 \mathrm{mg} / \mathrm{ml}$ in methanol for method I: It is prepared by transferring $10 \mathrm{ml}$ degradation product stock solution $(1 \mathrm{mg} / \mathrm{ml})$ into a $100 \mathrm{ml}$ volumetric flask and the volume was completed with methanol.

Working degradation product solution (DP Deg I) $0.01 \mathrm{mg} / \mathrm{ml}$ in methanol for method IIA and IIB: It is prepared by transferring $1 \mathrm{ml}$ degradation product stock solution $(1 \mathrm{mg} / \mathrm{ml})$ into a $100 \mathrm{ml}$ volumetric flask and the volume was completed with methanol.

\section{General procedures}

1D spectrophotometry (Method I): Linearity and construction of calibration curves: Aliquots equivalent to $2-120 \mu \mathrm{g} / \mathrm{mL}$ of $\mathrm{DP}$ and $5-120 \mu \mathrm{g} / \mathrm{mL}$ of VR standard solution $(100 \mu \mathrm{g} / \mathrm{ml})$ were transferred into two separate sets of $10 \mathrm{ml}$ volumetric flasks. The volume was completed with methanol so that the final concentration is in the range of $0.2 \mu \mathrm{g} / \mathrm{mL}$ to $12 \mu \mathrm{g} / \mathrm{mL}$ and $0.5 \mu \mathrm{g} / \mathrm{mL}$ to $12 \mu \mathrm{g} / \mathrm{mL}$ for DP and VR, respectively.

Then 1D spectra of each sample solution was computed with scaling factor of 10 and $\Delta \lambda$ of $4 \mathrm{~nm}$. The peak amplitudes of $1 \mathrm{D}$ for both DP and VR at $240 \mathrm{~nm}$ and $227 \mathrm{~nm}$ were measured, respectively.

Linear calibration curves were constructed by plotting the peak amplitudes at $240 \mathrm{~nm}$ and $227 \mathrm{~nm}$ to the corresponding concentrations of DP and VR, respectively, and the regression equations were computed.

Laboratory-prepared mixtures contain different ratios of DP and VR in presence of hydrolytic degradation product of DP.

Aliquots $(1.08 \mathrm{ml}$ to $0.12 \mathrm{ml})$ of DP and co-formulated drug VR were accurately transferred from their working solutions $(0.1 \mathrm{mg} / \mathrm{mL})$ equivalent to $(108 \mu \mathrm{g} / \mathrm{mL}$ to $12 \mu \mathrm{g} / \mathrm{mL})$ into a series of $10 \mathrm{~mL}$ volumetric flasks.

Aliquots $(0.12 \mathrm{ml}$ to $10.08 \mathrm{ml})$ of DP degradation product working solutions $(0.1 \mathrm{mg} / \mathrm{mL})$ equivalent to $(12 \mu \mathrm{g} / \mathrm{mL}$ to $108 \mu \mathrm{g} / \mathrm{mL})$ were added and then volumes were made up with methanol to prepare mixtures containing ( $10 \%$ to $90 \% \mathrm{w} / \mathrm{w})$ of the degradation product. The procedure described under linearity was then followed and the percentage recoveries of the each drug were calculated from the corresponding regression equation.
Synchronous fluorescence spectroscopy (Method II): Method IIALinearity and construction of calibration curves: Aliquots equivalent to $0.1 \mu \mathrm{g} / \mathrm{mL}$ to $10 \mu \mathrm{g} / \mathrm{mL}$ of DP and $0.1 \mu \mathrm{g} / \mathrm{mL}$ to $7 \mu \mathrm{g} / \mathrm{mL}$ TD were transferred into two separate series of $10 \mathrm{ml}$ volumetric flasks. The volume was then completed with acetonitrile so that the final concentration is in the range of $(0.01 \mu \mathrm{g} / \mathrm{mL}$ to $1 \mu \mathrm{g} / \mathrm{mL})$ and $(0.01$ $\mu \mathrm{g} / \mathrm{mL}$ to $0.7 \mu \mathrm{g} / \mathrm{mL}$ ) for $\mathrm{DP}$ and $\mathrm{TD}$, respectively.

The instrument was adjusted to synchronous mode by scanning both monochromators at a constant wavelength difference at $\Delta \lambda$ of 70 $\mathrm{nm}$, the normal synchronous spectra were recorded within the range of $200 \mathrm{~nm}-350 \mathrm{~nm}$ against acetonitrile as a blank. The synchronous fluorescence intensities of TD were measured at $\lambda \mathrm{em} 212 \mathrm{~nm}$ (no interference from DP).

Linear calibration curves were constructed by plotting the normal synchronous fluorescence intensities of TD at $212 \mathrm{~nm}$ to the corresponding concentrations of TD and the regression equation was computed.

Linearity and construction of calibration curves: Method IIB: After following the procedures mentioned in method IIA, the first derivative synchronous fluorescence scan FDSFS of DP and its degradation and co-formulated drug TD were derived from the normal synchronous spectra using FI Solution software at $\Delta \lambda 70 \mathrm{~nm}$, and the fluorescence intensities of FDSFS were estimated at $295 \mathrm{~nm}$ and $242 \mathrm{~nm}$ both DP and TD, respectively. A blank experiment was performed simultaneously.

A Linear calibration graph was constructed relating the peak amplitudes of FDSFS at $295 \mathrm{~nm}$ and $242 \mathrm{~nm}$ to the corresponding concentrations of DP and TD, respectively, and the regression equations were computed.

Laboratory-prepared mixtures contain different ratios of DP and TD in presence of hydrolytic degradation product of DP.

Aliquots $(0.63 \mathrm{ml}$ to $0.07 \mathrm{ml})$ of $\mathrm{DP}$ and co-formulated drug TD were accurately transferred from their working solutions $(0.01 \mathrm{mg} / \mathrm{mL})$ equivalent to $6.3 \mu \mathrm{g} / \mathrm{mL}$ to $0.7 \mu \mathrm{g} / \mathrm{mL}$ into a series of $10 \mathrm{~mL}$ volumetric flasks.

Aliquots $(0.07 \mathrm{ml}$ to $0.63 \mathrm{ml})$ of $\mathrm{DP}$ degradation product working solutions $(0.01 \mathrm{mg} / \mathrm{mL})$ equivalent to $(0.7 \mu \mathrm{g} / \mathrm{mL}$ to $6.3 \mu \mathrm{g} / \mathrm{mL})$ were added, and then volumes were made up with acetonitrile to prepare mixtures containing (10\% to $90 \%)$ of the degradation product. The procedures described under linearity method (II A and IIB) were then followed the percentage recoveries of the each drug were calculated from the corresponding regression equation.

\section{Application to pharmaceutical formulation}

Ten tablets of Snovitra Super Power ${ }^{\circledR}$ tablets or T-ject ${ }^{\oplus}$ tablets were separately weighed and finely powdered. An accurately weighed amount of the powdered tablets equivalent to $60 \mathrm{mg}$ of DP and $20 \mathrm{mg}$ of VR (Method I) and equivalent to $60 \mathrm{mg}$ of DP and $20 \mathrm{mg}$ of TD (Method IIA and IIB) were transferred into two separate $100 \mathrm{ml}$ volumetric flask. $50 \mathrm{ml}$ methanol was added and the two solutions were sonicated by shaking in ultrasonic bath for about $30 \mathrm{~min}$. The volumes was then completed to the mark with methanol and filtered. Suitable dilutions were made using methanol to prepare a tablet solutions containing $0.1 \mathrm{mg} / \mathrm{ml}$ (Method I) or $0.01 \mathrm{mg} / \mathrm{ml}$ (Method IIA and IIB). Aliquots of each tablet solution were diluted with the appropriate solvent to obtain final concentration within the working concentration ranges. The procedure previously described under each 
Citation: Soliman SM, El-Azizy HMY, EI Bayomi AEA (2017) Validated Stability-Indicating Derivative Spectrophotometry and Synchronous Fluorescence Spectroscopy Methods for the Determination of Dapoxetine Hydrochloride in the Presence of its Degradation Product and Co-Formulated Drugs. Pharm Anal Acta 8: 564. doi:10.4172/2153-2435.1000564

Page 4 of 11

method was followed and standard addition techniques were applied. The concentrations of standard added were calculated from the corresponding regression equation.

\section{Results and Discussion}

The stability of DP was studied according to ICH guidelines [26] for acid stress using $0.1 \mathrm{M}, 1 \mathrm{M} \mathrm{HCl}$ for $10 \mathrm{~h}, 2 \mathrm{M}, 3 \mathrm{M} \mathrm{HCl}$ for $10 \mathrm{~h}, 4 \mathrm{M}$ $\mathrm{HCl}$ for $20 \mathrm{~h}$ and $5 \mathrm{M} \mathrm{HCl}$ for $20 \mathrm{~h}$ and $30 \mathrm{~h}$.

The degradation processes were monitored by TLC using toluenemethanol $(8.5: 1.5 \mathrm{v} / \mathrm{v})$ as a mobile phase. DP was found to be liable to acid degradation and appearance of only one spot after complete degradation indicates formation of a single component. The structure of the isolated acid degradation product of DP was confirmed by TLC and MS.

The IR spectrum of intact DP (Figure 2A) is characterized by C-H stretching aromatic at $3050 \mathrm{~cm}^{-1}, \mathrm{C}=\mathrm{C}$ aromatic at $1600 \mathrm{~cm}-1$ and $\mathrm{O}-\mathrm{R}$ ether function group at $1100 \mathrm{~cm}^{-1}$. On the other hand, the IR spectrum of DP degradation product (Figure $2 \mathrm{~B}$ ) indicates a broad band of a hydrogen bond (appearance of -OH stretching) at $3426 \mathrm{~cm}^{-1}, \mathrm{C}-\mathrm{H}$ stretching aliphatic at $2924 \mathrm{~cm}^{-1}$ and the spectrum showed absence of the characteristic $\mathrm{O}-\mathrm{R}$ ether function group present in the IR spectrum of the intact DP at $1100 \mathrm{~cm}^{-1}$.

A mass spectrum of degraded DP (Figure 2C) shows the mass ion peak of $\mathrm{C}_{11} \mathrm{H}_{17} \mathrm{NO}$ at $(\mathrm{m} / \mathrm{z} 180.34)$. The other fragment was suggested to be naphthalene which is known to be volatile. These studies suggested the degradation pathway and confirm the structure of the hydrolytic degradation products of DP. The proposal of the reaction pathway of DAP with $5 \mathrm{M} \mathrm{HCl}$ was presented in (Scheme 1).

\section{D spectrophotometry (Method I)}

Derivative spectrophotometry $[27,28]$ has proved to be usefulness and simple technique for quantitative analysis, characterization, and quality control of drugs in mixtures. This technique offers various advantages over the conventional methods such as the enhancement of the resolution of specific spectral interference from degradation products, co-formulated drugs, and the elimination of interference from the non-specific absorption from other formulation components.

In Method A, the recorded zero order absorption spectra (0D) of DP and VR showed overlapped spectra in the range of $200 \mathrm{~nm}-350$ $\mathrm{nm}$, as described in (Figure 3). DP is liable to degradation under acidic condition. The hydrolytic degradation product that was formed exhibited a detectable absorbance and also shows an interfering spectrum with DP and VR. This observation prevents the use of direct analysis of DP in presence of its degradation and co-formulated drug VR, as shown in (Figure 3). Therefore, the first derivative method 1D was applied to resolve this overlapping. Upon examining the $1 \mathrm{D}$ spectra of DP, its degradation and the co-formulated drug VR, it was observed that DP and VR were found to exhibit zero crossing point at the maxima of the selected drug and at zero crossing point of the interfering one, where the hydrolyzed degradation has no contribution and exhibits zero reading.

DP can be a determined at $\lambda 240 \mathrm{~nm}$ (Figure 4) in presence of its acidic degradation and the co-formulated VR, also VR could be analyzed at $\lambda 227 \mathrm{~nm}$ (Figure 5) in presence of DP and its acidic degradation.
Linearities were obtained between the values of peak amplitudes of $1 \mathrm{D}$ at specified wavelengths and the corresponding concentrations of the drugs in the range of 0.2 to 12 and $0.5 \mu \mathrm{g} / \mathrm{mL}$ - to $12 \mu \mathrm{g} / \mathrm{mL}-1$ for $\mathrm{DP}$ and VR in methanol, respectively.

The proposed stability-indicating 1D method was successfully applied for determination of DP and VR in drug substances in presence of DP degradation product up to $90 \%$ without interference with mean recoveries of $99.90 \pm 0.98 \%$ and $99.83 \pm 0.94 \%$, respectively, as shown in Table 1.
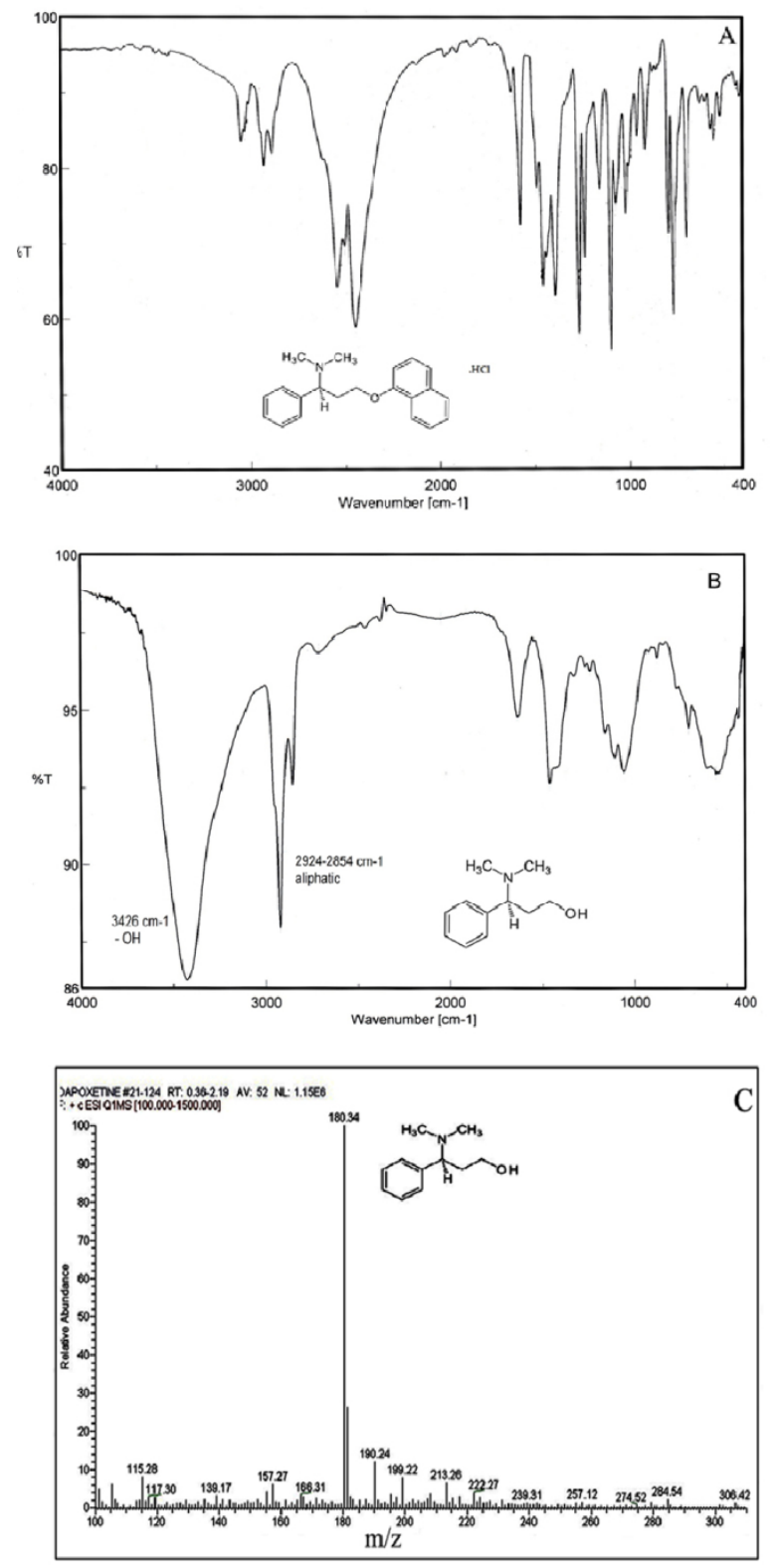

Figure 2: (A) IR spectra of dapoxetine. (B) (+)-N, N-dimethyl-1phenyl-3-propanolamine (Deg 1) of dapoxetine. (C) Mass spectrum of (Deg 1) of dapoxetine. 
Citation: Soliman SM, El-Azizy HMY, EI Bayomi AEA (2017) Validated Stability-Indicating Derivative Spectrophotometry and Synchronous Fluorescence Spectroscopy Methods for the Determination of Dapoxetine Hydrochloride in the Presence of its Degradation Product and Co-Formulated Drugs. Pharm Anal Acta 8: 564. doi:10.4172/2153-2435.1000564

Page 5 of 11

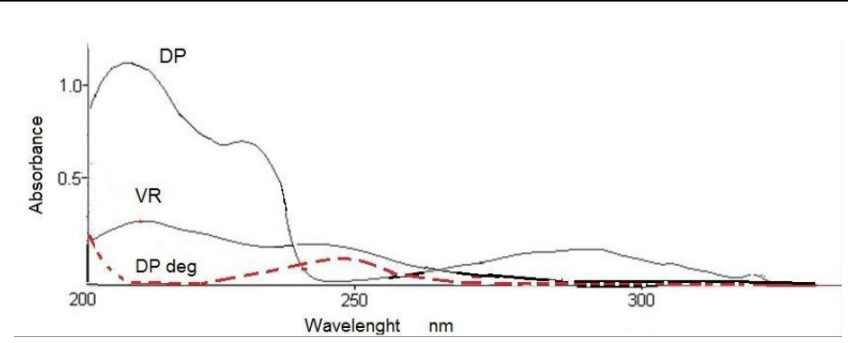

Figure 3: Zero order absorption spectra of DP and its degradation product $(9 \mu \mathrm{g} / \mathrm{ml}$ each $)$ and VR $(3 \mu \mathrm{g} / \mathrm{ml})$ in methanol.

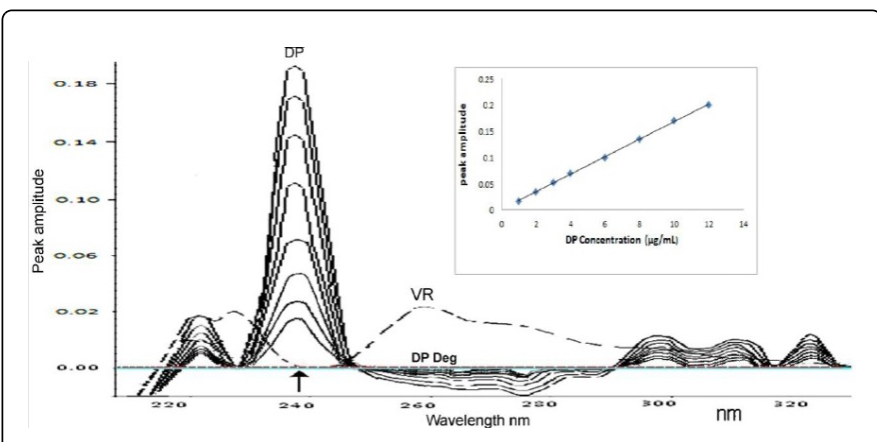

Figure 4: Linearity of the first derivative spectra of DP (0.2-12 $\mu \mathrm{g} / \mathrm{mL})$ at $\lambda 240 \mathrm{~nm}$, its degradation product and VR $(12 \mu \mathrm{g} / \mathrm{mL}$ each) in methanol.

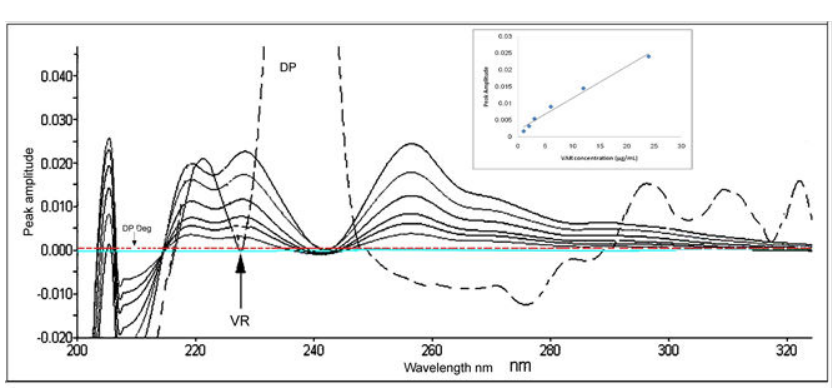

Figure 5: Linearity of the first derivative spectra of VR (0.5-12 $\mu \mathrm{g} / \mathrm{mL})$ at $\lambda 227 \mathrm{~nm}, \mathrm{DP}$ and its degradation product $(12 \mu \mathrm{g} / \mathrm{mL}$ each) in methanol.

\section{Synchronous fluorescence spectroscopy}

The excitation and emission spectra of DP in acetonitrile were recorded in the range of $200 \mathrm{~nm}-500 \mathrm{~nm}$ as shown in (Figure 6), it exhibit maximum emission at $366 \mathrm{~nm}$ when excited at $235 \mathrm{~nm}$ and 299 $\mathrm{nm}$. While, a similar concentration of DP degradate solution has no fluorescence emission at the same excitation wavelength. TD also showed native fluorescence in acetonitrile solution, it exhibit maximum emission at $\lambda$ em $360 \mathrm{~nm}$ after an excitation maximum at $290 \mathrm{~nm}$. Both the excitation and emission spectra of DP and TD are greatly overlapped (Figure 6). Therefore, the SFS technique was proposed for analysis of DP, TD in presence of degradation product of DP.

A synchronous fluorescence spectroscopy SFS has become a wellestablished technique for the determination of drugs in mixtures and combined dosage forms due to the considerable advantages of spectral simplification, light scattering reduction, and selectivity improvement over spectrophotometry and conventional fluorometry [29]. The selectivity and resolution are further enhanced by the combination of SFS approaches with derivative technique (DSFS) [30].

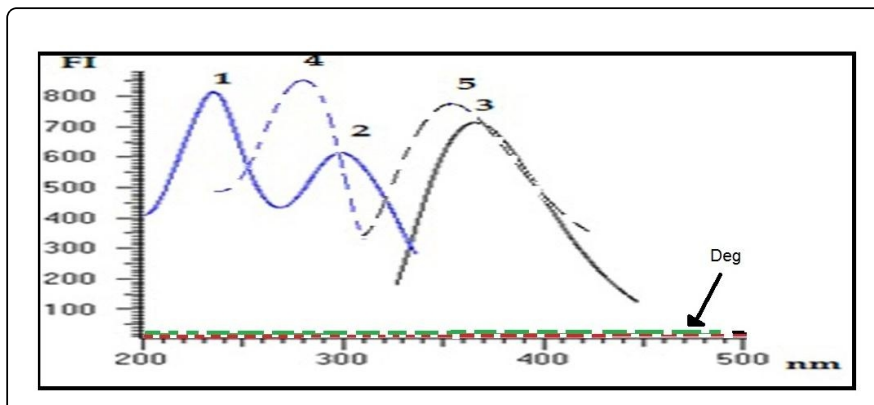

Figure 6: Excitation $(1,2,4)$ and emission $(3,5)$ spectra of DP and its degradation product $(0.9 \mu \mathrm{g} / \mathrm{ml}$ each at $\lambda \mathrm{ex}=235,299 \mu \mathrm{nm}$ and $\lambda \mathrm{em}=366 \mathrm{~nm})$ and TD $(0.3 \mu \mathrm{g} / \mathrm{ml}$ at $\lambda \mathrm{ex} / \mathrm{em}=290 / 360 \mathrm{~nm}) ; \mathrm{DP}$ $(1,2,3)$; TD $(4,5)$ in acetonitrile.

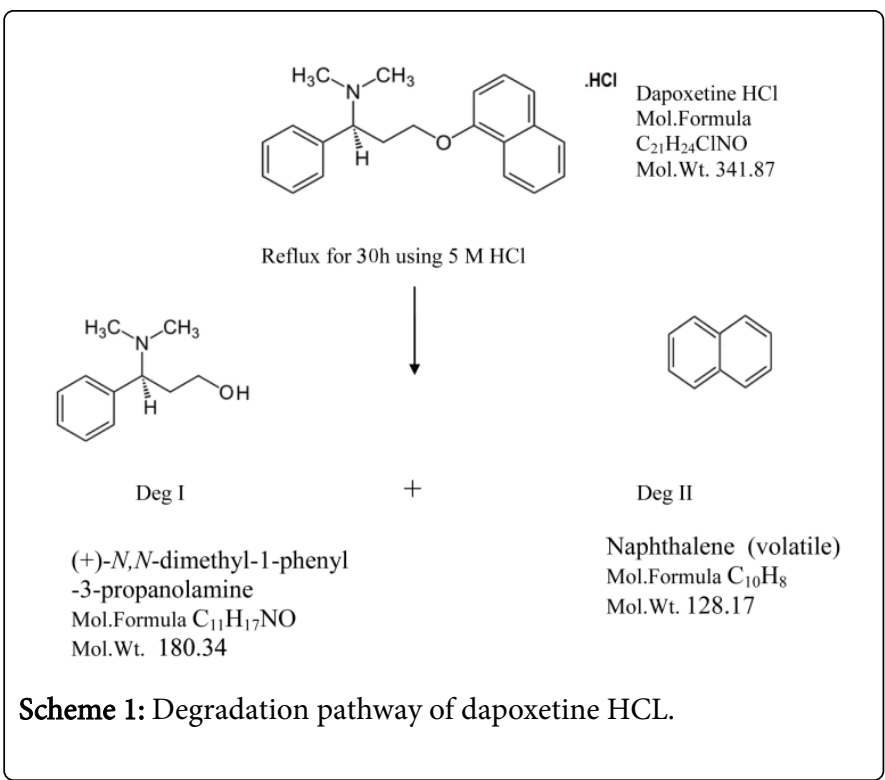

The proposed stability-indicating SFS (Method II) were successfully applied for determination of TD (Method IIA) and analysis of DP and 
Citation: Soliman SM, El-Azizy HMY, EI Bayomi AEA (2017) Validated Stability-Indicating Derivative Spectrophotometry and Synchronous Fluorescence Spectroscopy Methods for the Determination of Dapoxetine Hydrochloride in the Presence of its Degradation Product and Co-Formulated Drugs. Pharm Anal Acta 8: 564. doi:10.4172/2153-2435.1000564

Page 6 of 11

\begin{tabular}{|c|c|c|c|c|c|}
\hline \multirow[t]{3}{*}{ Parameter } & \multicolumn{2}{|c|}{ 1D Spectrophotometry } & \multicolumn{3}{|c|}{ Spectrofluorometry methods } \\
\hline & \multirow[t]{2}{*}{ DP at $238 \mathrm{~nm}$} & \multirow[t]{2}{*}{ VR at $227 \mathrm{~nm}$} & \multirow{2}{*}{$\begin{array}{l}\text { SFS } \\
\text { TD at } 212 \mathrm{~nm}\end{array}$} & \multicolumn{2}{|l|}{ FDSFS } \\
\hline & & & & DP at $295 \mathrm{~nm}$ & TD at $242 \mathrm{~nm}$ \\
\hline Rang $\mu \mathrm{g} / \mathrm{mL}$ & $0.2-12$ & $0.5-12$ & $0.01-0.7$ & $0.01-1.0$ & $0.01-0.7$ \\
\hline Slope & 0.016 & 0.0001 & $2.4 \times 10-3$ & $3.6 \times 10-3$ & $17.6 \times 10-3$ \\
\hline SD of slope & 0.002 & 0.00007 & 0.0001 & 0.007 & 0.009 \\
\hline Intercept & 0.012 & 0.002 & $0.166 \times 10-3$ & $0.97 \times 10-3$ & $1.21 \times 10-3$ \\
\hline SD of intercept & 0.003 & 0.00001 & 0.0014 & 0.003 & 0.009 \\
\hline$(r)^{a}$ & 0.9991 & 0.9989 & 0.9989 & 0.9991 & 0.9975 \\
\hline LOD $^{b}$ & 0.07 & 0.18 & $1.9 \times 10-3$ & $3.0 \times 10-3$ & $1.7 \times 10-3$ \\
\hline LOQ $^{\mathrm{b}}$ & 0.2 & 0.5 & $5.8 \times 10-3$ & $8.3 \times 10-3$ & $5.1 \times 10-3$ \\
\hline Accuracy $^{c}$ & $99.90 \pm 0.98$ & $99.83 \pm 0.94$ & $98.54 \pm 0.52$ & $99.70 \pm 0.98$ & $99.00 \pm 0.62$ \\
\hline Selectivity ${ }^{d}$ & $98.93 \pm 0.65$ & $99.28 \pm 0.71$ & $99.61 \pm 0.96$ & $99.47 \pm 0.34$ & $99.22 \pm 0.80$ \\
\hline \multicolumn{6}{|l|}{ Precision RSD\% } \\
\hline Intra-day & 0.82 & 1.1 & 0.63 & 0.49 & 0.64 \\
\hline Inter-day ${ }^{f}$ & 1.25 & 1.25 & 0.7 & 0.53 & 0.7 \\
\hline
\end{tabular}

Table 1: Assay validation report of the proposed methods for the simultaneous determination of DP, VR and DP, TD in their drug substances. ${ }^{\mathrm{a} C}$ Correlation coefficient, ${ }^{\mathrm{b}} \mathrm{LOD}=3.3 \mathrm{SD} /$ slope, ${ }^{\mathrm{b}} \mathrm{LOQ}=10 \mathrm{SD} /$ slope. ${ }^{\mathrm{c} A c c u r a c y}$ (mean $\pm \mathrm{SD}$ ) average of five determinations. ${ }^{\mathrm{d}}$ Selectivity (mean \pm SD) for the laboratory prepared mixtures. ${ }^{e}$ Repeatability $(n=3)$, RSD of three different concentrations of the cited drugs repeated three times

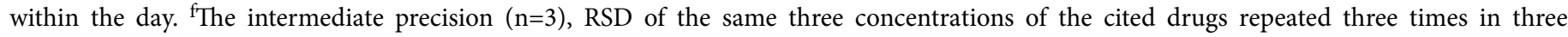
successive days.

Method IIA: The SFS was employed for analysis of TD using $\Delta \lambda$ of $70 \mathrm{~nm}$ (no interference from DP) in the presence of DP and its hydrolytic degradation product in drug substances and co-formulated tablets. The SFS technique depends upon the native fluorescence of both DP and VR observed in acetonitrile due to the presence of conjugated systems in their fused aromatic rings and the absence of fluorescence of DP degradation product solution (Scheme 1). Different concentrations of DP $(0.01 \mu \mathrm{g} / \mathrm{ml}$ to $1 \mu \mathrm{g} / \mathrm{ml})$ at $280 \mathrm{~nm}$ in presence of its degradation product of DP $(1 \mu \mathrm{g} / \mathrm{ml})$ and TD $(0.3 \mu \mathrm{g} / \mathrm{ml})$ were represented, where no complete spectral resolution was observed for $\mathrm{DP}$ (Figure 7). On the other hand, TD in concentration range $(0.01 \mu \mathrm{g} /$ $\mathrm{ml}-0.7 \mu \mathrm{g} / \mathrm{ml}$ ) was determined using SFS technique in presence of DP and its degradation product $(1 \mu \mathrm{g} / \mathrm{ml}$ each $)$ and quantified at $212 \mathrm{~nm}$ without any interference of DP or its degradation product as given in (Figure 8).

TD (Method IIB) in bulk powder in the presence of DP degradation product up to $90 \%$ without interference with mean recoveries of 98.54 $\pm 0.52 \%, 99.70 \pm 0.98 \%$ and $99.00 \pm 0.62 \%$, respectively, as shown in Table 1.

\section{Optimization of the proposed experimental conditions}

To optimize the proposed 1D method it was necessary to study the influence of different variables; for example, the effect of different smoothing factors $(\Delta \lambda$ at 2,4 , and 8$)$ values and scaling factor $(C F)$ values $(10,100$ and 1000$)$ were studied. A smoothing factor at $\Delta \lambda=4$ and $\mathrm{CF}=10$ were selected proved good spectral resolution of DP and VR.

The effect of different solvents (Figures 11 and 12) was examined including bi-distilled water, methanol, ethanol and acetonitrile. It was observed that methanol gave the highest absorbance values of DP and VR in (Method I) (Figure 11). A significant hyperchromic effect was observed in acetonitrile which gave the highest FI and the lowest blank reading for DP and TD (Figure 12). 
Citation: Soliman SM, El-Azizy HMY, EI Bayomi AEA (2017) Validated Stability-Indicating Derivative Spectrophotometry and Synchronous Fluorescence Spectroscopy Methods for the Determination of Dapoxetine Hydrochloride in the Presence of its Degradation Product and Co-Formulated Drugs. Pharm Anal Acta 8: 564. doi:10.4172/2153-2435.1000564

Page 7 of 11

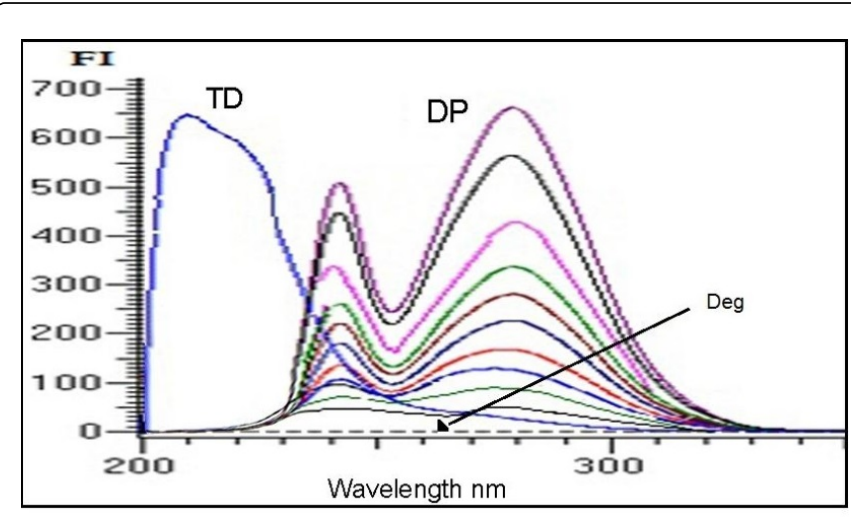

Figure 7: Linearity of synchronous fluorescence spectra of DP $(0.01-1 \mu \mathrm{g} / \mathrm{ml})$, its degradation product $(1 \mu \mathrm{g} / \mathrm{ml})$ at $280 \mathrm{~nm}$ and $\mathrm{TD}(0.3 \mu \mathrm{g} / \mathrm{ml})$ in acetonitrile.

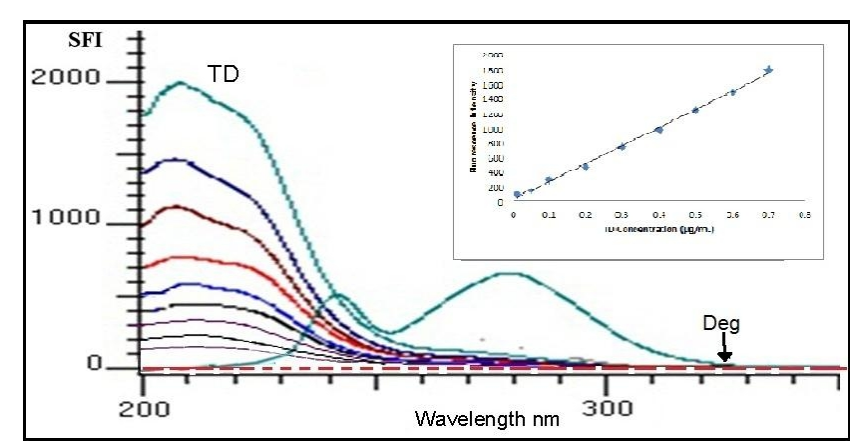

Figure 8: Linearity of synchronous fluorescence spectra of TD (0.01 $\mu \mathrm{g} / \mathrm{ml}-0.7 \mu \mathrm{g} / \mathrm{ml})$ at $212 \mathrm{~nm}, \mathrm{DP}$ and its degradation product $(1$ $\mu \mathrm{g} / \mathrm{ml}$ each) in acetonitrile.

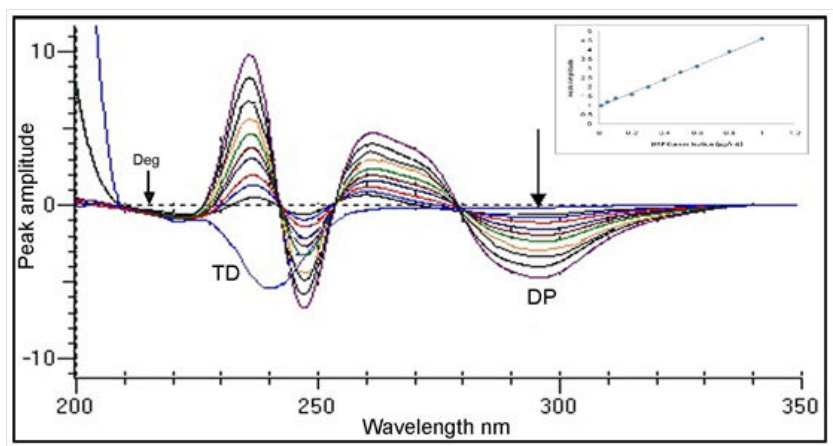

Figure 9: Linearity of the first derivative synchronous fluorescence spectra FDSFS of DP $(0.01-1 \mu \mathrm{g} / \mathrm{ml})$ at $295 \mathrm{~nm}$, its degradation product $(1 \mu \mathrm{g} / \mathrm{ml})$, and $\mathrm{TD}(0.3 \mu \mathrm{g} / \mathrm{ml})$ in acetonitrile.
Method IIB: FDSFS using zero-crossing technique was performed, which resulted in complete spectral resolution and enabled determination of DP and its co-formulated drug TD in the presence of DP degradation at $\Delta \lambda$ of $70 \mathrm{~nm}$ in acetonitrile. Linearities were obtained between the values of amplitudes of FDSFS at $295 \mathrm{~nm}$ and $242 \mathrm{~nm}$ and the corresponding concentrations of the cited drugs in concentration ranges of $(0.01 \mu \mathrm{g} / \mathrm{ml}$ to $1 \mu \mathrm{g} / \mathrm{ml})$ and $(0.01 \mu \mathrm{g} / \mathrm{ml}$ to 0.7 $\mu \mathrm{g} / \mathrm{ml}$ ) for determination of DP and TD, respectively, as shown in (Figures 9 and 10).

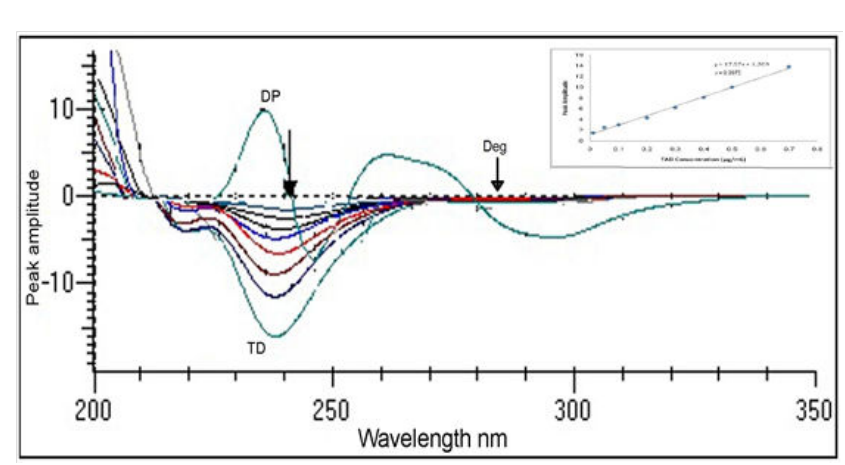

Figure 10: Linearity of the first derivative synchronous fluorescence spectra FDSFS of TD $(0.01-0.7 \mu \mathrm{g} / \mathrm{ml})$ at $242 \mathrm{~nm}$, DP and its degradation product $(1 \mu \mathrm{g} / \mathrm{ml})$ in acetonitrile.

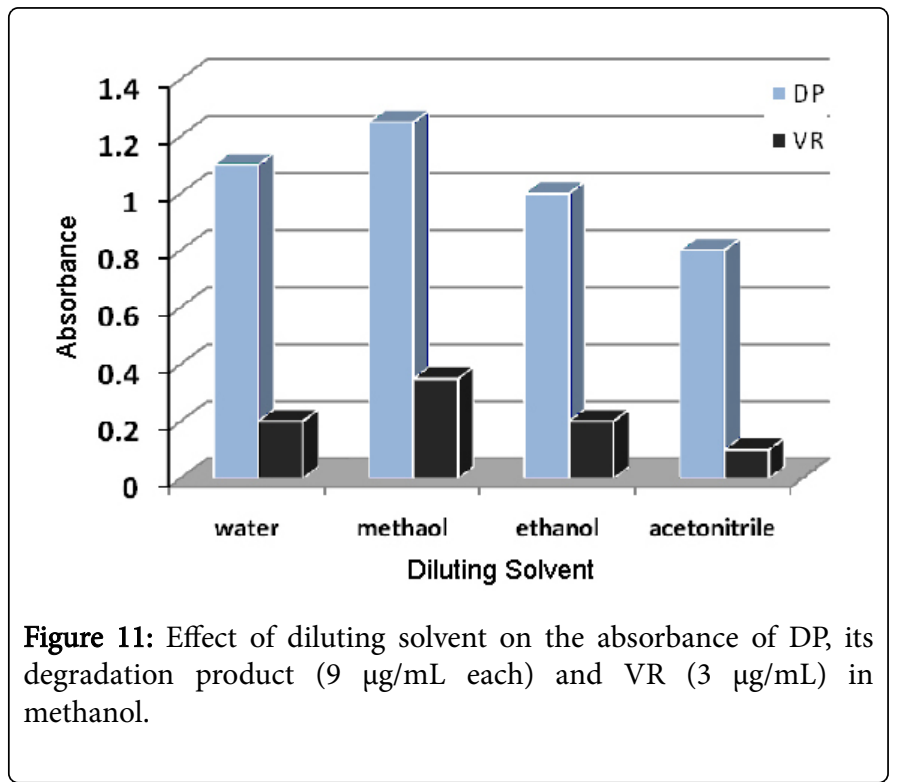

The main important principle stated by the green chemistry is to use safer solvents that generate less hazardous waste, less harmful to humans and to the environment [31,32]. Hence methanol and acetonitrile were selected as diluting solvents for the proposed methods. 
Citation: Soliman SM, El-Azizy HMY, EI Bayomi AEA (2017) Validated Stability-Indicating Derivative Spectrophotometry and Synchronous Fluorescence Spectroscopy Methods for the Determination of Dapoxetine Hydrochloride in the Presence of its Degradation Product and Co-Formulated Drugs. Pharm Anal Acta 8: 564. doi:10.4172/2153-2435.1000564

Page 8 of 11

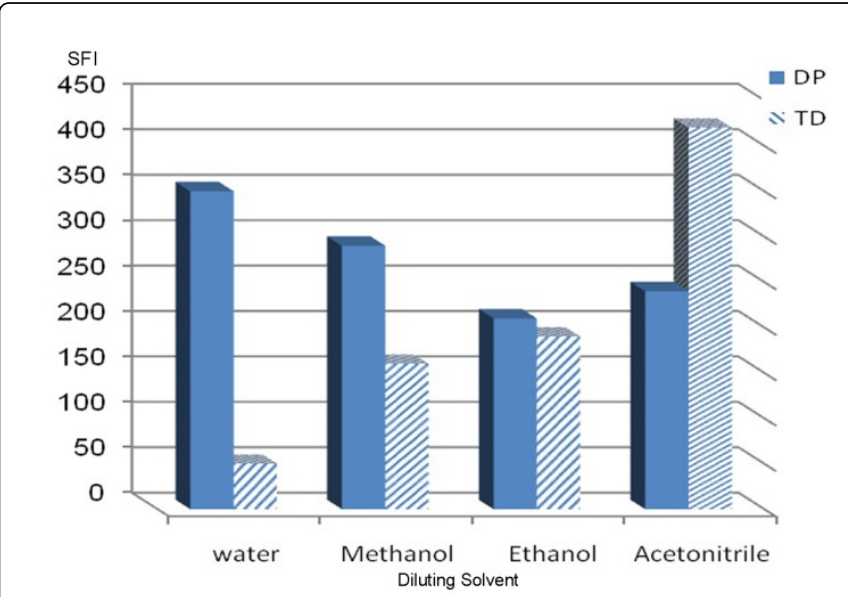

Figure 12: Effect of diluting solvent on the SFI of DP, its degradation product $(0.3 \mu \mathrm{g} / \mathrm{ml}$ each) and (TD $0.1 \mu \mathrm{g} / \mathrm{ml})$ in acetonitrile.

In method II, Different experimental and instrumental parameters affecting the performance of SFS were carefully studied and optimized. They include scanning range, the effect of optimal $\Delta \lambda$ on SFS, excitation and emission band width and diluting solvents.

The synchronous wavelength range of 200 to 700 was scanned while changing $(\Delta \lambda)$. The effect of different values of $\Delta \lambda$ on the resolution of the emission spectra of both DP and TD from $(\Delta \lambda$ of 10 to $100 \mathrm{~nm})$ was examined, and the observation indicates $\Delta \lambda$ of $70 \mathrm{~nm}$ gave the best result for resolution of both drugs, since it reduced the spectral interference caused by each compound in the mixture (Figures 9 and 10). Various excitation and emission band width were tested $(5,10$ and $20 \mathrm{~nm}$ ) and fixed at $5 \mathrm{~nm}$, where it provides high fluorescence intensities.

In addition, the effect of time on stability of the fluorescence intensity was also studied and the result indicates that the intensity of the developed fluorescence was stable up to $2 \mathrm{~h}$.

\section{Method Validation}

Validation of the proposed methods was assessed as per ICH guidelines [33].

Linearity: The linearity of the proposed methods was evaluated by triplicate analysis of the same concentration range as the corresponding calibration graph. The characteristic parameters of the regression equations are stated in (Table 1).

Repeatability and intermediate precision: Repeatability as intra-day precision was studied by analysing freshly prepared solutions of concentrations $(0.5 \mu \mathrm{g} / \mathrm{ml}, 5 \mu \mathrm{g} / \mathrm{ml}$ and $12 \mu \mathrm{g} / \mathrm{ml})$ of DP and VR (method A), $(0.01 \mu \mathrm{g} / \mathrm{ml}, 0.3 \mu \mathrm{g} / \mathrm{ml}$ and $0.7 \mu \mathrm{g} / \mathrm{ml}$ ) of TD (SFS method B) and $(0.05,0.1$ and $0.7 \mu \mathrm{g} / \mathrm{ml})$ of each of DP and TD (FDSFS method B) in triplicate within the same day. The inter-day precision was studied by analysis of the same concentrations in triplicate for three successive days to determine variation observed from the proposed methods, which was expressed as\% RSD. The results are listed in (Table $1)$.

Detection and quantification limits: The sensitivity of the proposed method was determined with respect to LOD and LOQ. The lowest detectable amount of the selected drugs that could be detected and quantified was calculated and the results were listed in (Table 1).

Accuracy: Accuracy studies were evaluated by assaying freshly prepared solutions of the cited drugs prepared at each recovery level and analyzed versus standard solutions. The percentage mean recovery values ranged from $98.54 \pm 0.52 \%$ to $99.90 \pm 0.98 \%$, indicating accurate results as summarized in (Table 1).

Also the Accuracy of the methods for assay of the cited drugs in tablets was tested by applying the standard addition technique. The obtained results indicate good recovery (Table 2).

Specificity: The specificity of the proposed methods was evaluated by analysis of laboratory-prepared mixtures containing different percentages of the selected drugs and different percentages of the DP degradation product. The results were recorded in (Table 3).

\begin{tabular}{|c|c|c|c|c|c|c|c|c|c|c|c|}
\hline \multicolumn{6}{|c|}{ 1D spectrophotometry Method I } & \multicolumn{6}{|c|}{ FDSFS Method IIB } \\
\hline \multicolumn{2}{|c|}{ Claimed taken $(\mu \mathrm{g} / \mathrm{mL})$} & \multicolumn{2}{|c|}{ Added $\mu \mathrm{g} / \mathrm{mL}$} & \multicolumn{2}{|c|}{ Recovery of standard added $\%$ a } & \multicolumn{2}{|c|}{ Claimed taken $(\mu \mathrm{g} / \mathrm{mL})$} & \multicolumn{2}{|c|}{ Added $\mu \mathrm{g} / \mathrm{mL}$} & \multicolumn{2}{|c|}{ Recovery of standard added $\%$ a } \\
\hline DP & VR & DP & VR & DP & VR & DP & TD & DP & TD & DP & TD \\
\hline 3 & 1 & 4 & 1 & 99.46 & 98.43 & 0.3 & 0.1 & 0.1 & 0.1 & 98.3 & 99.33 \\
\hline 3 & 1 & 5 & 2 & 101.2 & 99.27 & 0.3 & 0.1 & 0.2 & 0.2 & 98.64 & 98.68 \\
\hline 3 & 1 & 6 & 3 & 98.66 & 100.7 & 0.3 & 0.1 & 0.3 & 0.3 & 99.87 & 99.42 \\
\hline 3 & 1 & 8 & 6 & 99.51 & 99.19 & 0.3 & 0.1 & 0.4 & 0.4 & 98.53 & 100.6 \\
\hline Mean & & & & 99.71 & 99.4 & & & & & 98.84 & 99.51 \\
\hline$\pm \mathrm{RSD}$ & & & & 1.07 & 0.95 & & & & & 0.7 & 0.8 \\
\hline
\end{tabular}

Table 2: Results of determination of DP, VR (Method I) and DP, TD by the proposed methods and application of standard addition technique. 
Citation: Soliman SM, El-Azizy HMY, El Bayomi AEA (2017) Validated Stability-Indicating Derivative Spectrophotometry and Synchronous Fluorescence Spectroscopy Methods for the Determination of Dapoxetine Hydrochloride in the Presence of its Degradation Product and Co-Formulated Drugs. Pharm Anal Acta 8: 564. doi:10.4172/2153-2435.1000564

Page 9 of 11

\begin{tabular}{|c|c|c|c|c|c|}
\hline \multicolumn{6}{|l|}{ Recovery ${ }^{\mathrm{a}}$ of intact drug $\%$} \\
\hline \multirow[t]{3}{*}{ Degradation $\%$ (w/w)of DP } & \multicolumn{2}{|l|}{ Method I } & \multicolumn{3}{|l|}{ Method II } \\
\hline & & & \multirow{2}{*}{$\begin{array}{l}\text { SFS IIA } \\
\text { TD at } 212 \mathrm{~nm}\end{array}$} & \multirow{2}{*}{$\begin{array}{l}\text { FDSFS IIB } \\
\text { DP at } 295 \mathrm{~nm}\end{array}$} & \multirow[b]{2}{*}{ TD at $242 \mathrm{~nm}$} \\
\hline & DP at $238 \mathrm{~nm}$ & VR at $227 \mathrm{~nm}$ & & & \\
\hline 10 & 98.13 & 100.8 & 100.66 & 99.41 & 100.99 \\
\hline 30 & 98.52 & 100.5 & 98.92 & 99.9 & 99.5 \\
\hline 50 & 100.3 & 99.7 & 101.41 & 99.39 & 99.88 \\
\hline 70 & 99.34 & 101.3 & 99.75 & 100.3 & 100.33 \\
\hline 80 & 99.3 & 99.9 & 99.4 & 100.8 & 98.75 \\
\hline 90 & 99.22 & 100.55 & 98.42 & 100.1 & 100.76 \\
\hline Meana \pm RSD $\%$ & $99.35 \pm 0.73$ & $100.63 \pm 064$ & $99.77 \pm 1.10$ & $99.70 \pm 0.98$ & $100.03 \pm 0.84$ \\
\hline
\end{tabular}

Table 3: Specificity results of the proposed methods for determination of DP, VR (Method I), TD (Method IIA) and DP, TD (Method IIB) in presence of degradation product of DP $(10-90 \mathrm{w} / \mathrm{w})$ in laboratory prepared mixtures.

In method I, a stability indicating $1 \mathrm{D}$ was specific for analysis DP and VR in presence of up to $90 \%$ of DP degradation product at $240 \mathrm{~nm}$ and $227 \mathrm{~nm}$, respectively.

In method IIA, SFS was specific for assay of DP in presence of up to $90 \%$ of its hydrolytic degradation product and up to $10 \%$ of coformulated drug TD at $280 \mathrm{~nm}$. SFS was specific for assay of TD in presence of DP its degradation product up to $90 \%$ at $212 \mathrm{~nm}$.

In method IIB, FDSFS was specific for determination of DP and TD in presence of up to $90 \%$ of degradation product of DP at $295 \mathrm{~nm}$ and $242 \mathrm{~nm}$, respectively (Table 3).

Stability: In the present study, methanol and acetonitrile were appropriate solvents for preparing standard stock solutions and laboratory-prepared mixtures solutions. The stability of DP or VR standard solutions in methanol and DP or TD standard solutions in acetonitrile were determined. The RSD\% values of analysis were below $2 \%$ which indicate stability of the selected drugs in the stock solutions for 3 days without significant changes.

Application of the proposed methods to pharmaceutical preparations: The usefulness of proposed methods to the analysis of DP and VR as well as DP and TD in their co-formulated preparations was studied. No interfering spectra were observed from any of the inactive ingredients. The direct assay of the cited drugs in their coformulated tablets without interference from the excipients proves the simplicity and selectivity of the proposed methods as shown in (Table
The proposed stability-indicating methods have also been employed to assay DP and VR in Snovitra Super Power expired tablets and also to quantify DP and TD in T-ject ${ }^{\circ}$ expired tablets in which minor degradations were occurred. The results were recorded in Table 4.

Statistical analysis: Recovery data obtained by the suggested methods for determination of drug substances were statistically compared to those obtained by the reference ones $[13,16]$ the calculated $\mathrm{t}$-and F-tests values did not exceed the theoretical ones, indicating no significant differences with respect to accuracy and precision as given in (Table 5).

\section{Conclusion}

The developed 1D spectrophotometry and FDSFS methods are simple, less expensive, time saving methods and environmentally friendly in comparison to the other published ones. They allow analysis of DP, VR and TD in drug substances, laboratory prepared mixtures and their co-formulated tablets without interference from excipients or DP hydrolytic degradation product up to $90 \%$, so they could be applied in QC laboratories for routine analysis. The acidic degradation products were defined as (+)-N, N-dimethyl-1-pheny 1-3propanolamine (Deg 1) and Naphthalene (Deg 2), confirmed by IR and Mass analysis. 
Citation: Soliman SM, El-Azizy HMY, EI Bayomi AEA (2017) Validated Stability-Indicating Derivative Spectrophotometry and Synchronous Fluorescence Spectroscopy Methods for the Determination of Dapoxetine Hydrochloride in the Presence of its Degradation Product and Co-Formulated Drugs. Pharm Anal Acta 8: 564. doi:10.4172/2153-2435.1000564

Page 10 of 11

\begin{tabular}{|c|c|c|c|c|c|c|}
\hline \multicolumn{7}{|l|}{ The proposed 1D spectrophotometry (Method I) } \\
\hline \multirow{2}{*}{$\begin{array}{l}\text { Product } \\
\text { Snovitra Super Power® tablet Batch No\# } 10800260 \mathrm{mg} \text { DP/20 mg VR/ } \\
\text { tablet }\end{array}$} & \multicolumn{2}{|c|}{ Concentration taken $\mu \mathrm{g} / \mathrm{mL}$} & \multicolumn{2}{|c|}{ Concentration found $\mu \mathrm{g} / \mathrm{mL}$} & \multicolumn{2}{|l|}{ Recoverya\% } \\
\hline & DP & VR & DP & VR & DP & VR \\
\hline & 12 & 4 & 11.917 & 3.942 & 99.31 & 98.56 \\
\hline & 9 & 3 & 8.971 & 2.962 & 99.68 & 98.72 \\
\hline & 6 & 2 & 6.036 & 1.989 & 100.6 & 99.46 \\
\hline \multirow{2}{*}{\multicolumn{5}{|c|}{ Mean \pm RSD Snovitra Super Power ${ }^{\circledR}$ tablet expired batch Batch No\# 080177}} & $99.86 \pm 0.66$ & $98.91 \pm 0.48$ \\
\hline & & & & & $98.45 \pm 0.26$ & $98.70 \pm 0.18$ \\
\hline \multicolumn{7}{|l|}{ The proposed FDSFS (Method IIB) } \\
\hline \multirow[t]{5}{*}{ T-ject $\circledast$ tablet Batch No\# 17603060 mgDP/20 mg TD/tablet } & \multicolumn{2}{|c|}{ Concentration taken $\mu \mathrm{g} / \mathrm{mL}$} & \multicolumn{2}{|c|}{ Concentration found $\mu \mathrm{g} / \mathrm{mL}$} & \multicolumn{2}{|l|}{ Recovery \% } \\
\hline & DP & TD & DP & TD & DP & TD \\
\hline & 0.3 & 0.1 & 0.2976 & 0.1001 & 99.2 & 100.1 \\
\hline & 0.6 & 0.2 & 0.5917 & 0.1986 & 98.61 & 99.31 \\
\hline & 0.9 & 0.3 & 0.8929 & 0.2977 & 99.21 & 99.24 \\
\hline \multirow{2}{*}{\multicolumn{5}{|c|}{ Mean \pm RSD T-ject $\circledast$ tablet expired batch Batch No\#07081 }} & $99.01 \pm 0.34$ & $99.55 \pm 0.48$ \\
\hline & & & & & $98.52 \pm 0.20$ & $97.11 \pm 0.14$ \\
\hline
\end{tabular}

Table 4: Results obtained for the determination of DP, VR (Method I) and DP, TD (Method IIB) in their co-formulated tablets by the proposed methods.

\begin{tabular}{|c|c|c|c|c|c|c|c|c|c|}
\hline \multirow[t]{3}{*}{ Items } & \multirow{3}{*}{$\begin{array}{l}{ }^{1} \mathrm{D} \text { spectrophotometry } \\
\text { Method I } \\
\text { DP }\end{array}$} & \multirow[b]{3}{*}{ VR } & \multicolumn{2}{|c|}{ Reported method ${ }^{a}$} & \multirow{3}{*}{$\begin{array}{l}\text { SFS } \\
\text { Method IIA } \\
\text { TD }\end{array}$} & \multirow{2}{*}{\multicolumn{2}{|c|}{ DSFS }} & \multicolumn{2}{|c|}{ Reported method ${ }^{\mathrm{b}}$} \\
\hline & & & \multirow[b]{2}{*}{$\mathrm{DP}$} & \multirow[b]{2}{*}{ VR } & & & & \multirow[b]{2}{*}{ DP } & \multirow[b]{2}{*}{ TD } \\
\hline & & & & & & DP & TD & & \\
\hline Mean & 99.9 & 99.83 & 99.31 & 99.38 & 98.54 & 99.7 & 99 & 99.22 & 99.02 \\
\hline SD & 0.98 & 0.94 & 0.61 & 1.54 & 0.52 & 0.98 & 0.62 & 1.35 & 1.02 \\
\hline Variance & 0.96 & 0.88 & 0.37 & 2.37 & 0.27 & 0.96 & 0.38 & 1.82 & 1.04 \\
\hline $\mathbf{n}$ & 5 & 5 & 5 & 5 & 5 & 5 & 5 & 5 & 5 \\
\hline \multirow[t]{2}{*}{ t-test ${ }^{c}$} & 1.14 & 0.56 & & & 0.94 & 0.64 & 0.04 & & \\
\hline & 2.306 & 2.306 & & & 2.306 & 2.306 & 2.306 & & \\
\hline \multirow[t]{2}{*}{ F-test ${ }^{c}$} & 2.58 & 2.68 & & & 3.85 & 1.9 & 2.71 & & \\
\hline & 6.388 & 6.388 & & & 6.388 & 6.388 & 6.388 & & \\
\hline \multicolumn{10}{|c|}{$\begin{array}{l}\text { aThe quantification was carried out on } \mathrm{C} 18 \text { column and a mobile phase consisting of buffer }(\mathrm{KH} 2 \mathrm{PO} 4) \text { : acetonitrile: triethylamine }(55: 45: 0.1 \mathrm{v} / \mathrm{v} / \mathrm{v}) \text { at } 266 \mathrm{~nm}(13) \\
\text { bDetermination s was achieved on } \mathrm{C} 18 \text { column with mobile phase consisting of acetonitrile: } 0.1 \% \text { triethyl amine in water } \mathrm{pH} 4.0(80: 20) \text { at } 229 \mathrm{~nm}(16) \text {. . } \\
{ }^{c} \text { The values in the parenthesis are the corresponding theoretical values of } \mathrm{t} \text { and } \mathrm{F} \text { at }(\mathrm{P}=0.05) \text {. }\end{array}$} \\
\hline
\end{tabular}

Table 5: Statistical analysis of the results obtained by the proposed methods and the reported ones for the determination of DP, VR (Method I), TD (Method IIA) and DP, TD (Method IIB) in their pure forms.

\section{References}

1. Moffat AC, Osselton MD, Widdop B, Galichet LY (2011) Clarke’s Analysis of Drugs and Poisons, 4th edn, The Pharmaceutical Press, Electronic version, London.

Pharm Anal Acta, an open access journal

ISSN: 2153-2435
2. Dresser MJ, Desai D, Gidwani S, Seftel AD, Modi NB (2006) Dapoxetine: A novel treatment for premature ejaculation, does not have Pharmacokinetic interaction with phosphodiesterase-5 inhibitors. Int J Impot Res 18: 104-110.

3. Block JH, Beale JM (2011) Wilson and Gisvold's textbook of organic medicinal and pharmaceutical chemistry, 12th edn, Philadelphia; Lippincott Williams and Wilkins. 
Citation: Soliman SM, El-Azizy HMY, EI Bayomi AEA (2017) Validated Stability-Indicating Derivative Spectrophotometry and Synchronous Fluorescence Spectroscopy Methods for the Determination of Dapoxetine Hydrochloride in the Presence of its Degradation Product and Co-Formulated Drugs. Pharm Anal Acta 8: 564. doi:10.4172/2153-2435.1000564

Page 11 of 11

4. Coward RM, Carson CC (2008) Tadalafil in the treatment of erectile dysfunction. Ther Clin Risk Manag 4: 1315-1330.

5. Sweetman SC (2014) The complete Drug Reference, 38th edn. The Pharmaceutical Press, London, UK, p: 2354-2386.

6. Andersson KE, Mulhall JP, Wyllie MG (2006) Pharmacokinetic and pharmacodynamic features of dapoxetine: A novel drug for 'on demand' treatment of premature ejaculation. Bju Int 97:311-315.

7. Nehra A (2007) Oral and non-oral combination therapy for erectile dysfunction. Rev Urol 9: 99-105.

8. Abdel-Moety MM, Souaya ER, Soliman EA (2015) Spectrophotometric methods for simultaneous determination of vardenafil and dapoxetine hydrochlorides in combined dosage form. World J Pharm Pharm Sci 4: 120-133.

9. Paghadar B, Antala H, Tala P, Dhudashia K, Patel N (2013) Q-absorbance ratio spectrophotometric method for the simultaneous estimation of vardenafil and dapoxetine hydrochloride in their combined dosage form. Int J Res Pharm Nano Sci 2: 124-129.

10. Savjiyani NB, Patel PB (2013) Simultaneous estimation of vardenafil hydrochloride and dapoxetine hydrochloride in combined pharmaceutical dosage form by spectrophotometry and RP-HPLC. I Amer J Pharm Res 3: 3652-3668.

11. Soliman SM, El-Agizy HMY, Bayoumi AE (2014) Derivative synchronous fluorescence spectroscopy for the simultaneous determination of dapoxetine hydrochloride and vardenafil in binary mixtures. J Appl Spectrosc 81: 509-518.

12. Chapla B, Amin G, Pandya A, Kakadiya J, Shah N (2012) Simultaneous estimation and validation of vardenafil and dapoxetine hydrochloride in pharmaceutical formulation by thin layer chromatographic densitometric method. Int Res J Pharm 3: 480-483.

13. Patel PD, Makwana CJ, Patel MD, Dey S, Upadhyay UM (2014) Development and validation of analytical method for simultaneous estimation of vardenafil and dapoxetine $\mathrm{HCl}$ in bulk and in combined dosage form. Int J Pharm Res Scholars 3: 17-30.

14. Amin GA, Chapla B, Pandya A, Kakadiya J, Baria D (2012) Development and validation of dual wavelength UV spectrophotometric method for simultaneous estimation of tadalafil and dapoxetine hydrochloride in their combined tablet dosage form. Int J Pharm Res Bio Sci 1: 247-255.

15. Hegazy M, Kessiba A, Abdelkawy M, elgendy A (2016) Synchronous fluorescence spectroscopy coupled with wavelet transforms and SavitzkyGolt derivatization technique for the simultaneous determination of tadalafil and dapoxetine hydrochloride. Int J Pharm Pharm Sci 18: 32-38.

16. Giri AD, Bhusari VK, Dhaneshwar SR (2012) Validated HPLC method for simultaneous quantitation of tadalafil and dapoxetine hydrochloride in bulk drug and formulation. Int J Pharm Pharm Sci 4:654-658.

17. Rajeshwari M, Chenthilnathan A, Rama K (2014) Validated RP-HPLC method for simultaneous estimation of tadalafil and dapoxetine hydrochloride in combined pharmaceutical dosage forms. Int J Pharm Pharm Biol Sci 4: 72-82.
18. Kolsure A, Hiremath R (2015) Development and validation of UV Spectrophotometric Area under Curve (AUC) method for dapoxetine $\mathrm{HCl}$ in pharmaceutical formulation. J Pharm Sci Bioscientific Res. 5: 475-478.

19. Kanani V (2013) Development and Validation of UV Spectrophotometric method for estimation of Dapoxetine HCL in bulk and dosage Form. Int J Drug Dev Res 5: 161-167.

20. Banik S (2014) A Simple and rapid validated UV spectrophotometric method for estimation of dapoxetine in bulk and tablet dosage form. Indian J Novel Drug Delivery 6: 277-281.

21. Rohith T, Ananda S (2012) A Validated chiral liquid chromatographic method for the enantiomeric separation of dapoxetine hydrochlorid. Int J Adv Res Pharm Biosci 3: 311-319.

22. Rohith T, Ananda S (2013) Development and validation of high performance liquid chromatography method for the determination of process related impurities in dapoxetine hydrochloride. IJRPC: 74-82.

23. Hamilton CL, Cornpropst JD (1993) Determination of dapoxetine, an investigational agent with the potential for treating depression, and its mono-and di-desmethyl metabolites in human plasma using columnswitching high-performance liquid chromatography. J Chromatography B 612: 253-261.

24. Patil RB, Deshmukh TA, Patil VP (2014) Stability-indicating HPLC methods for determination of dapoxetine HCL in bulk drug and formulation. Int J Pharm Pharm Sci 6: 687-690.

25. Liew KB, Peh KK (2014) Stability indicating HPLC-UV method for determination of dapoxetine $\mathrm{HCl}$ in pharmaceutical product. Acta Pol Pharm 71: 393-400.

26. ICH Q1A (R2) (2000) Stability Testing of new drug substances and products.

27. Sanchez RF, Ojeda BC, Pavon CJM (1988) Derivative ultraviolet-visible region absorption spectrophotometry and its analytical applications. Talanta 35: 753-761.

28. Sánchez RF, Bosch Ojeda C (2009) Recent development in derivative ultraviolet/visible absorption spectrophotometry. Anal Chim Acta 635: 22-44.

29. Chen GZ, Huang XZ, Xu JG, Zheng ZZ, Wang ZB (1990) The Methods of Fluorescence Analysis, Science Press, Beijing, P.R. China. pp: 112.

30. Lakowicz JR (2006) Principles of Fluorescence Spectroscopy, 3rd edn, New York.

31. Keith LH, Gron LU, Young JL (2007) Green analytical methodologies. Chem Rev 107: 2695-2708.

32. Anastas PT (1999) Green chemistry and the role of analytical methodology development. Crit Rev Anal Chem 29:167-175.

33. ICH Q2B (R1) (2005) Validation of analytical procedures: Text and methodology. 